\title{
Post Exercise Glycogen in Activity Related to Ingestion of Carbohydrates and Protein Mixture through Gymnastics Training Program.
}

\author{
Ayat Y. Bagato \\ Lecturer of sports physiology, Department of biological sciences and sports health. Faulty of physical education, \\ Helwan University, Egypt.
}

\section{Mohamed Samy Mahmoud}

Lecture of gymnastic training, Departement of gymnastic training, Faculty of physical education, Menufia University, Egypt.

\begin{abstract}
Background: Regular intensive gymnastic exercise activities causes muscle glycogen and protein depletion. Post-exercise recovery helps re-synthesis of glycogen and proteins. Ingestion of carbohydrates alone or with protein after exercise stimulates re-synthesis. All previous studies investigated tissue biopsies for estimating glycogen and protein resynthesis. The initiation of glycogen synthesis is provided by a self-glucosylation of a protein self extracting enzyme glycogenin under the control of insulin and blood glucose levels. Plasma glycogenin could be used as a good marker for glycogen resynthesis.

Methods: Sixteen male students from the faculty of physical education for boys, Menufia University, grade four were constituted subjects of this study. They were subgrouped in two equal groups, subjected to a gymnastic training program for three months. The first group (control) ingested sucrose at the end of every training session while the second (experimental) ingested a mixture of $\mathrm{CHO} /$ protein beverage. Their anthropometric measurements and blood glycogenin-1, insulin and glucose were assayed and correlated.
\end{abstract}

Results: All variables were revealed significant improvement in all physical measurements with increased response of post exercise blood levels in glycogenin-1 and insulin with administration of post-exercise sucrose or CHO/protein drinks with most higher results of the mixture .

Conclusions: It is concluded that gymnastic training program with post exercise carbohydrate or CHO/protein intake increase the physical efficiency with improved high performance.

Key words: Plasma glycogenin-1, insulin, plasma glucose levels, CHO/protein, gymnastic training program, physical measurements.

\section{Introduction:}

Drolonged sub-maximal exercise is dramatically reduce the muscle and liver glycogen. Mode of exercise and the volume, intensity, and frequency of the training sessions induce muscle adaptations, causing marked change in the storage profile of skeletal muscles glycogen (Hawley et al., 2011). Also, muscle protein synthesis is decreased during an acute bout of resistance exercise; however, during post-exercise recovery the rate of glycogen and muscle protein synthesis is increased under control of insulin. Furthermore, ingesting of 
protein/carbohydrate in close to the end of exercise enhances the metabolic response of post-exercise recovery (Breen et al., 2011).

Glycogen -the storage form of carbohydrateis stored in many tissues with the major depots located in muscle and liver. Muscle glycogen is degraded to generate ATP during increased energy demand, whereas hepatic glycogen is broken down, releasing glucose into the bloodstream to supply other tissues. During recovery, glycogen re-synthesis starts at strictly ordered process, resulting in a complex structure (Melendez et al., 1999 and Roach (2002). Post-exercise muscle glycogen synthesis is an important factor in determining the time needed to recover from prolonged exercise (van Loon et al., 2000).

Glycogenin is a glycogen re-synthesizing enzyme initiates granule formation by the addition of about 7-11 glucose residues to a single tyrosine residue on its apo-protein. Then, glycogen synthase utilizes UDPglucose to transfer glucose molecules by $1-4$ linkages to glycogen, which is the ratecontrolling step of glycogen synthesis (Greenberg et al., 2006). Although it is appreciated that glycogenin is essential for the formation of a glycogen granule, its regulation has rarely been studied in human plasma. Glycogenin-1 (42 kDa) content is abundant in skeletal muscle, responsible for muscle and tissue glycogen re-synthesis (Shearer et al., 2005).

Protein ingestion after a single bout of resistance-type exercise stimulates net muscle protein accretion during post-exercise recovery. Consequently, it is generally accepted that protein supplementation is required to maximize the adaptive response of the skeletal muscle to prolonged resistance-type exercise training (Cermak et al., 2012). Also, Reidy et al. (2013) found that protein ingestion following resistance exercise promotes human muscle protein synthesis.

Recent work has shown that the ingestion of whole proteins such as whey or casein with carbohydrate $(\mathrm{CHO})$ following resistance exercise accelerate muscle protein synthesis following an acute bout of resistance exercise (Elliot et al., 2006, Koopman et al., 2005 \& Koopman et al., 2007) or when ingested chronically following 3 months of resistance exercise training (Fujita et al., 2007). Zawadzki et al. (1992) reported that addition of an intact protein to a carbohydratecontaining solution resulted in higher glycogen synthesis rates in subjects after exercise than did ingestion of carbohydrate only.

However, there is much discrepancy in the literature regarding the proposed benefits of regular protein/carbohydrate supplementation during recovery from exercise through training program. Also, all previous studies interested in muscle biopsy for assessing glycogen re-synthesis. Very rare studies concerned plasma constituents for assaying glycogen re-synthesis in the recovery period. The aim of this study was to evaluate the effect of chronic post-exercise ingestion of carbohydrate/protein mixture on the adaptation process and glycogen recovery rate after gymnastics training program in a three months period.

Plasma insulin, glycogenin-1 and glucose concentrations were measured pre-exercise, 1 hour post-exercise and 3 hours later to determine glycogen synthesis activity and muscle glycogen content. Anthropometric measurements including circumferences of chest, nick, upper arm, thigh and calf were assayed before and after the training program. 
Material and Methods:

\section{Subjects:}

Sixteen male students from the faculty of physical education for boys, Menofia University, grade four were volunteered for this study. They were recruited for the study after completing a medical questionnaire and giving their informed, written consent. All experimental procedures were approved by the Helwan University Human Research Ethics. Participants were divided into two groups as control who received sucrose beverage and second experimental group received $\mathrm{CHO} /$ Protein mixture beverage at the end of every training session.

\section{Study design:}

In the present study, subjects were subjected to prolonged gradual increasing intensity to be sub-maximal gymnastics exercise $(\sim 50 \%$ to 90 of $\mathrm{VO} 2 \max$ ) to reduce the muscle glycogen and then sucrose or sucrose/protein mixture were administrated to discover the rate of glycogen re-synthesis during recovery and muscle adaptations after training program for three months. We started at intensity of $50 \%$ of $\mathrm{VO} 2 \mathrm{max}$ and increased by $10 \%$ every two weeks for two months, then by $5 \%$ every two weeks in the third month. We tested for changes in plasma glycogenin-1, insulin and levels of plasma glucose levels under these conditions. Also, anthrpometric adaptation including circumferences of chest, neck, arm, thigh and calf muscles before and after the training program.

\section{Program design:}

Subjects were subjected to the intense upgraded gymnastic program for 12 weeks for 3hrs/ 3 days/ week. The gymnastics exercise session was partitioned as prescribed in the following table.

\begin{tabular}{|c|c|c|c|c|c|c|c|c|}
\hline Exercises & Warming Up & Flexibility & Anaerobic & Aerobic & Technique & Resistance & Flexibility & Sum \\
\hline minutes & 20 & 15 & 20 & 20 & 70 & 20 & 15 & 180 \\
\hline
\end{tabular}

\section{CHO/Protein supplementation:}

Subjects received a beverage volume of 2 $\mathrm{ml} / \mathrm{kg} 15 \mathrm{~min}$ after exercise to ensure a given dose of $1.0 \mathrm{~g} / \mathrm{kg}$ carbohydrate only $(\mathrm{CHO})$ for control group, or a dose of $0.8 \mathrm{~g} / \mathrm{kg}$ carbohydrate with $0.2 \mathrm{~g} / \mathrm{kg}$ protein (CHO/PRO) for experimental group.

This supplementation regimen has been proven effective to allow a continuous supply of glucose and amino acids from the gut and, as such, to minimize perturbations in plasma glucose, amino acid, and circulating insulin concentrations during recovery (Beelen et al., 2011). Sucrose was used as the carbohydrate supplement while milk casein protein was used as the protein portion of the mixture.

\section{Blood analysis:}

Blood samples at rest were collected under aseptic conditions from the anti-cubital vein. Post-exercise blood sampling was performed immediately after the exercise and three hours later. Samples were collected in tubes containing coagulation activator, centrifuged and kept at $-20 \quad \mathrm{C}^{\circ}$ until tested. Plasma glycogenin-1 and insulin levels were determined using a commercial ELISA kits provided by Teco medical group, Germany. Glucose was measured colorimetrically using kits provided by Randox, England. 


\section{Statistical analysis:}

All data are expressed as means \pm SD. The plasma insulin, glucose, and glycogenin levels in control group were compared to that obtained in experimental group by T. test. A two-factor repeated-measures analysis of variance (ANOVA) was used to compare differences between treatments within the same group. Statistical significance was set at $\mathrm{P} \leq 0.05$. All calculations were performed using SPSS Statistics 17.0 (SPSS, Chicago, IL).

\section{Results:}

Table (1) postulate anthropometric measurements obtained from the students before and after the training program in both groups. There are significant differences of arithmetic means of all anthropometric data between initial measurements of the experimental group students compared to the post-training program results. Control group data was also significant except for calf muscle and weight.

(Table 1)

Anthropometric data obtained for control and experimental groups (Before compared to after program)

\begin{tabular}{|c|c|c|c|c|c|}
\hline \multicolumn{6}{|c|}{ Control $($ Mean \pm SD) } \\
\hline & Before & After & $\mathbf{T}$ & $\mathbf{p}$ & Sig. \\
\hline Chest (circum. Cm) & $91.21 \pm 1.17$ & $92.97 \pm 1.36$ & -7.47 & $\mathbf{0 . 0 0}$ & $\mathbf{S}$ \\
\hline Neck (circum. Cm) & $36.28 \pm 1.48$ & $37.43 \pm 1.64$ & -4.97 & $\mathbf{0 . 0 0}$ & $\mathbf{S}$ \\
\hline Arm (circum. Cm) & $30.13 \pm 1.34$ & $32.1 \pm 0.99$ & -5.66 & 0.00 & $\mathbf{S}$ \\
\hline Thigh (circum. Cm) & $46.81 \pm 1.46$ & $47.77 \pm 1.45$ & -2.63 & $\mathbf{0 . 0 3}$ & $\mathbf{S}$ \\
\hline Calf (circum. Cm) & $32.35 \pm 0.74$ & $33.11 \pm 1.69$ & -1.35 & 0.22 & NS \\
\hline Height (cm) & $168.12 \pm 4.26$ & $\mathbf{x x x}$ & $\mathbf{x x x}$ & $\mathbf{x x x}$ & \\
\hline Weight (kg) & $63.75 \pm 2.23$ & $64.25 \pm 3.28$ & -1.12 & 0.30 & NS \\
\hline Age (years) & $21.125 \pm 0.83$ & $\mathbf{x x x}$ & $\mathbf{x x x}$ & $\mathbf{x x x}$ & \\
\hline \multicolumn{6}{|c|}{ Experimental $($ Mean \pm SD $)$} \\
\hline & Before & After & $\mathbf{T}$ & $\mathbf{p}$ & \\
\hline Chest (circum. Cm) & $91.36 \pm 1.23$ & $93.75 \pm 1.28$ & -11.10 & $\mathbf{0 . 0 0}$ & $\mathbf{S}$ \\
\hline Neck (circum. Cm) & $36.31 \pm 1.37$ & $37.87 \pm 1.64$ & -10.59 & $\mathbf{0 . 0 0}$ & $\mathbf{S}$ \\
\hline Arm (circum. Cm) & $30.16 \pm 1.39$ & $31.62 \pm 1.19$ & -12.10 & 0.00 & $\mathbf{S}$ \\
\hline Thigh (circum. Cm) & $46.38 \pm 1.41$ & $48.12 \pm 1.64$ & -13.28 & 0.00 & $\mathbf{S}$ \\
\hline Calf (circum. Cm) & $32 \pm 1.78$ & $33.75 \pm 1.67$ & -17.50 & 0.00 & $\mathbf{S}$ \\
\hline Height (cm) & $168.5 \pm 4.44$ & $\mathbf{x x x}$ & $\mathbf{x x x}$ & $\mathbf{x x x}$ & \\
\hline Weight (kg) & $63 \pm 3.66$ & $64.25 \pm 3.28$ & -5.00 & 0.00 & $\mathbf{S}$ \\
\hline Age (years) & $21 \pm 1.07$ & $\mathbf{x x x}$ & $\mathbf{x x x}$ & $\mathbf{x x x}$ & \\
\hline
\end{tabular}


(Table 2)

Anthropometric data obtained for control compared to experimental group (Before and after program)

\begin{tabular}{|c|c|c|c|}
\hline \multicolumn{2}{|c|}{ Control compared to experimental groups before program } \\
\hline & $\mathbf{t}$ & $\mathbf{p}$ & Sig. \\
\hline Chest (circum. Cm) & -0.46 & 0.66 & NS \\
\hline neck (circum. Cm) & -0.13 & 0.90 & NS \\
\hline arm (circum. Cm) & -0.07 & 0.94 & NS \\
\hline thigh (circum. Cm) & 1.41 & 0.20 & NS \\
\hline calf (circum. Cm) & 0.65 & 0.54 & NS \\
\hline height (cm) & -0.46 & 0.66 & NS \\
\hline weight (kg) & 1.25 & 0.25 & NS \\
\hline age (years) & 0.36 & 0.73 & NS \\
\hline Control compared to experimental groups after program & \\
\hline Chest (circum. Cm) & -3.31 & 0.01 & S \\
\hline neck (circum. Cm) & -3.92 & 0.01 & S \\
\hline arm (circum. Cm) & 1.70 & 0.03 & S \\
\hline thigh (circum. Cm) & -1.78 & 0.12 & NS \\
\hline calf (circum. Cm) & -3.28 & 0.01 & S \\
\hline
\end{tabular}

There is no statistically significant difference start of the study (Table 2). All physical in any of the anthropometric parameters parameters were found to be differed after obtained data between the two groups at the the program.

(Table 3)

Difference between experimental and control groups biochemical parameters $\quad(t$ test) (Mean \pm SD)

\begin{tabular}{|c|c|c|c|c|c|}
\hline & \multicolumn{5}{|c|}{ Before program } \\
\hline & Control & experimental & $\mathbf{t}$ & $\mathbf{p}$ & Sig. \\
\hline & \multicolumn{5}{|c|}{ Pre exercise } \\
\hline GLU (mg/dl) & $82.6 \pm 6.17$ & $81.6 \pm 3.1$ & .419 & .685 & NS \\
\hline Insulin ( umol/ml) & $16.6 \pm 3.39$ & $17.37 \pm 3.62$ & -.788 & .451 & NS \\
\hline \multirow[t]{2}{*}{ Glycogenin-1 (pg/ml) } & $35.35 \pm 7.07$ & $40.85 \pm 7.98$ & -1.637 & .136 & NS \\
\hline & \multicolumn{5}{|c|}{ After 1 hour } \\
\hline GLU (mg/dl) & $82.7 \pm 3.86$ & $81.4 \pm 4.33$ & .652 & .531 & NS \\
\hline Insulin ( umol/ml) & $26.2 \pm 6.83$ & $37.72 \pm 4.97$ & -3.604 & .006 & $\mathbf{S}$ \\
\hline \multirow[t]{2}{*}{ Glycogenin-1 (pg/ml) } & $65.11 \pm 9.47$ & $63.27 \pm 11.45$ & .435 & .673 & NS \\
\hline & \multicolumn{5}{|c|}{ After 3 hours } \\
\hline GLU (mg/dl) & $82.9 \pm 4.95$ & $81.2 \pm 4.05$ & .953 & .365 & NS \\
\hline Insulin ( umol/ml) & $21.07 \pm 3.31$ & $39.92 \pm 9.12$ & -6.722 & .000 & $\mathbf{S}$ \\
\hline
\end{tabular}




\begin{tabular}{|c|c|c|c|c|c|}
\hline & \multicolumn{5}{|c|}{ Before program } \\
\hline & Control & experimental & $\mathbf{t}$ & $\mathbf{p}$ & Sig. \\
\hline & \multicolumn{5}{|c|}{ Pre exercise } \\
\hline \multirow[t]{4}{*}{ Glycogenin-1 (pg/ml) } & $42.26 \pm 9.1$ & $41.94 \pm 4.73$ & .103 & .920 & NS \\
\hline & \multicolumn{5}{|c|}{ After program } \\
\hline & Control & experimental & $\mathbf{t}$ & $\mathbf{p}$ & Significance \\
\hline & \multicolumn{5}{|c|}{ Pre exercise } \\
\hline GLU (mg/dl) & $82.00 \pm 3.83$ & $82.00 \pm 3.33$ & .000 & 1.000 & NS \\
\hline Insulin ( umol/ml) & $18.95 \pm 6.45$ & $17.24 \pm 2.84$ & .631 & .544 & NS \\
\hline \multirow[t]{2}{*}{ Glycogenin-1 (pg/ml) } & $37.87 \pm 12.47$ & $44.00 \pm 7.2$. & -1.159 & .276 & NS \\
\hline & \multicolumn{5}{|c|}{ After 1 hour } \\
\hline GLU (mg/dl) & $81.4 \pm 2.91$ & $84.6 \pm 5.27$ & -1.489 & .171 & NS \\
\hline Insulin ( umol/ml) & $34.21 \pm 6.20$ & $64.4 \pm 8.73$ & -13.352 & .000 & $\mathbf{S}$ \\
\hline \multirow[t]{2}{*}{ Glycogenin-1 (pg/ml) } & $75.96 \pm 8.94$ & $80.34 \pm 6.35$ & -1.277 & .234 & NS \\
\hline & \multicolumn{5}{|c|}{ After 3 hours } \\
\hline GLU (mg/dl) & $83.1 \pm 4.53$ & $81.7 \pm 3.23$ & .924 & .379 & NS \\
\hline Insulin ( umol/ml) & $28.58 \pm 7.29$ & $54.6 \pm 4.97$ & -8.567 & .000 & $\mathbf{S}$ \\
\hline Glycogenin-1 (pg/ml) & $50.66 \pm 8.31$ & $53.52 \pm 6.87$ & -.947 & .369 & NS \\
\hline
\end{tabular}

Biochemical results obtained for both groups were compared in table (3). Both groups were equivalent at rest before exercise either before or after the program. After exercise with an hour or three hours, only insulin levels were elevated either before or after the program indicating that $\mathrm{CHO} /$ Protein beverage has an acute and chronic effects on the recovery state. 
(Table 4)

Analysis of difference (ANOVA) for control and experimental group biochemical parameters $($ Mean \pm SD)

\begin{tabular}{|c|c|c|c|c|c|c|}
\hline \multicolumn{7}{|c|}{ control before program } \\
\hline & Pre-exercise & After $1 \mathrm{hr}$. & After 3 hrs. & $\mathbf{F}$ & $\mathbf{p}$ & Sig. \\
\hline GLU (mg/dl) & $82.6 \pm 6.17$ & $82.7 \pm 3.86$ & $82.9 \pm 4.95$ & 0.004 & 0.99 & NS \\
\hline Insulin ( umol/ml) & $16.6 \pm 3.39$ & $26.2 \pm 6.83$ & $21.07 \pm 3.31$ & 7.95 & 0.002 & $\mathbf{S}$ \\
\hline Glycogenin-1 (pg/ml) & $35.35 \pm 7.07$ & $65.11 \pm 9.47$ & $42.26 \pm 9.1$ & 29.11 & 0.001 & $\mathbf{S}$ \\
\hline \multicolumn{7}{|c|}{ control group after program } \\
\hline & Pre-exercise & After $1 \mathrm{hr}$. & After 3 hrs. & $\mathbf{F}$ & $\mathbf{p}$ & Sig \\
\hline GLU (mg/dl) & $82.00 \pm 3.83$ & $81.4 \pm 2.91$ & $83.1 \pm 4.53$ & 0.51 & 0.606 & NS \\
\hline Insulin ( umol/ml) & $18.95 \pm 6.45$ & $34.21 \pm 6.20$ & $28.58 \pm 7.29$ & 13.41 & 0.001 & $\mathbf{S}$ \\
\hline Glycogenin-1 (pg/ml) & $37.87 \pm 12.47$ & $75.96 \pm 8.94$ & $50.66 \pm 8.31$ & 37.05 & 0.001 & $\mathbf{S}$ \\
\hline \multicolumn{7}{|c|}{ experimental group before program } \\
\hline & Pre-exercise & After 1 hr. & After 3 hrs. & $\mathbf{F}$ & $\mathbf{p}$ & Sig \\
\hline GLU (mg/dl) & $81.6 \pm 3.1$ & $81.4 \pm 4.33$ & $81.2 \pm 4.05$ & 0.02. & 0.97 & NS \\
\hline Insulin ( umol/ml) & $17.37 \pm 3.62$ & $37.72 \pm 4.97$ & $39.92 \pm 9.12$ & 38.35 & 0.001 & $\mathbf{S}$ \\
\hline Glycogenin-1 (pg/ml) & $40.85 \pm 7.98$ & $63.27 \pm 11.45$ & $41.94 \pm 4.73$ & 22.06 & 0.001 & $\mathbf{S}$ \\
\hline \multicolumn{7}{|c|}{ experimental group after program } \\
\hline & Pre-exercise & After $1 \mathrm{hr}$. & After 3 hrs. & $\mathbf{F}$ & $\mathbf{p}$ & Sig \\
\hline GLU (mg/dl) & $82.00 \pm 3.33$ & $84.6 \pm 5.27$ & $81.7 \pm 3.23$ & 1.54 & 0.23 & NS \\
\hline Insulin ( umol/ml) & $17.24 \pm 2.84$ & $64.4 \pm 8.73$ & $54.6 \pm 4.97$ & 17.4 & 0.001 & $\mathbf{S}$ \\
\hline Glycogenin-1 (pg/ml) & $44.00 \pm 7.2$. & $80.34 \pm 6.35$ & $53.52 \pm 6.87$ & 76.48 & 0.001 & $\mathbf{S}$ \\
\hline
\end{tabular}

Analysis of variance for every group concerning pre-exercise compared to after 1 hour and three hours post-exercise resulted in significant differences in insulin and glycogenin-1 levels in plasma but not glucose (table 4). These results reveal high anabolic metabolism in the recovery period regardless the type of beverage consumed.

\section{Discussion}

The main cause of this study was investigating plasma insulin, glycogenin-1 and glucose as a precursor for post-exercise resynthesis. Glycogenin-1 was found to be elevated markedly after an hour and three hours of exercise with drinking sucrose or
$\mathrm{CHO}$ /protein beverage. Also, it is more elevated at the end of the program up to double fold of resting levels meaning response to the program with $\mathrm{CHO} /$ protein drink. Insulin levels were elevated postexercise either before or after program with highest significant levels after program with $\mathrm{CHO} /$ protein beverage compared to sucrose only.

The primary finding from our study was that muscle protein synthesis (expressed by increased muscle circumstance) increased post-exercise in both the $\mathrm{CHO} /$ Protein group and control (CHO only) group. But performing a program of gymnastic training exercise with $\mathrm{CHO} /$ protein ingestion lead to 
further increase in muscle protein synthesis during post-exercise recovery compared with the control group.

Protein ingestion after a single bout of resistance-type exercise stimulates net muscle protein accretion during post-exercise recovery. Consequently, it is generally accepted that protein supplementation is required to maximize the adaptive response of the skeletal muscle to prolonged resistance-type exercise training (Cermak et al., 2012). Also, Reidy et al. (2013) found that protein ingestion following resistance exercise promotes human muscle protein synthesis

These data are in agreement with a large number of studies in which nutrient ingestion (i.e., amino acids, protein, or essential amino acids/ carbohydrates (EAA/CHO) following a bout of resistance exercise has been shown to increase muscle protein synthesis in human subjects (Biolo et al., 1997, Borsheim et al., 2002, Dreyer et al., 2008 \& Elliot et al., 2006). In addition, recent work has shown that when subjects ingested fat-free milk (i.e., protein/CHO) following each resistance exercise bout (during 3 months of training), the increase in muscle mass was greater than in either an iso-energetic soy protein group or an iso-energetic $\mathrm{CHO}$ control group (Hartman et al., 2007). Fujita et al. (2009). Although all these studies concerned same subject, but all of the investigated muscle biopsies.

Findings of this study revealed nonsignificant elevation in plasma glucose in the all investigated stages of the study. Decreasing muscle glycogen content after exercise may play a role, because the activation of AMP kinase (AMPK) and its associated increases in muscle glucose uptake are affected by glycogen content (Wojtaszewski et al., 2002). During exercise, continued muscle contraction lead to glycogen breakdown with increased extracellular glucose uptake and utilization (Greenberg et al., 2006). Glucose transport into the muscle is increased, correlated acutely with enhanced glucose protein carrier GLUT4 translocation to the plasma membrane (Rasmussen et al., 2002). According to these mechanisms, glucose remains constant in plasma through all investigation periods. This also can be explained by the observed additional increase in plasma insulin concentrations after ingestion of the carbohydrate-protein mixture. Elevated insulin concentrations may lead to increased glucose uptake (Hartman et al., 2007) and to an increase in glycogen synthase activity (Hasten et al., 2000 \& Jorfeldt and Wahren 1971), which forms the major factor in determining the rate of glycogen synthesis when the substrate supply is adequate ((Fujita et al., 2007 \& Kim et al., 2005).

Insulin elevation was found to increase after exercise with or without additives. Brun et al. (1995) found insulin to increase after a single bout of exercise at $85 \%$ of maximal heart rate (HR), they reported that glucose effectiveness and insulin sensitivity markedly increased at $25 \mathrm{~min}$ of recovery after 60-min hard exercise at $85 \%$ of estimated maximum HR that corresponded to about $70-80 \%$ VO2 max. Rheaume et al., (2003) demonstrated insulin elevation at (70-80\% VO2 max) and Mikines et al., (1998) at 70\% VO2 max and at $(65 \%$ VO2 max). Insulin stimulated recruitment of glucose transporter (GLUT-4) to the plasma membrane and activation of glycogen synthase in muscle are the major mechanisms responsible for the enhanced insulin-stimulated glucose transport and metabolism (Sakamoto and Goodyear, 2002). 
Although this study investigated plasma glycogenin-1, there were very few studies investigated glycogenin in tissue biopsies. Kraniou et al. (2000) and Shearer et al. (2005 $[\mathrm{A} \& \mathrm{~B}])$ have suggested that during recovery from prolonged exercise $\mathrm{GN}-1$ is synthesized to facilitate new granule formation and glycogen (especially pro-glycogen) resynthesis. To date, there have been no comprehensive examinations of this possibility. Intense exercise bout reduce muscular glycogen by $75-85 \%$ without GN-1 protein decrease or its mRNA increase even during recovery despite a doubling of glycogen concentration by $2 \mathrm{~h}$ of recovery with $\mathrm{CHO}$ administration. Within $5 \mathrm{~h}$ of recovery, total glycogen levels were resynthesized to be about $80 \%$ of resting levels (Wilson et al., 2007).

Glycogenin-1 (GN-1) catalyzes the addition of glucose units by 1-4 linkage to form an oligosaccharide chain of 7-11 glucose units in length, each attached by a1-4 linkages. Once complete, this chain is acted upon by glycogen synths and phosphorylase and transferred to glycogen by 1-6 linkage. All residues are removed except for the last one attached by Tyr194, whose bond (C-1-O tyrosyl linkage) is not accessible by the enzyme (Shearer et al., 2005 [A]).

It is discussed that elevated plasma GN-1 in exercise training may be due to loss of cell facultative permeability induced by elevated waste products or may be due to increased white blood cells activities during exercise leading to increased GN-1 production and passing to blood stream (Blom et al., 1986 \&1987). These results need more investigations concerning white blood cells glycogenin-1 mRNA and/or re-investigate previous studies hypothesis of muscular glycogenin-1 translational DNA response.
In conclusion, chronic $\mathrm{CHO} /$ protein ingestion post-exercise appears to be more effective (than ingestion of $\mathrm{CHO}$ only) at inducing further increases in the rate of human skeletal muscle protein and glycogen synthesis during early post-exercise recovery.

\section{References}

1. Beelen M, Zorenc A, Pennings B, Senden JM, Kuipers H, van Loon LJ. (2011) Impact of protein coingestion on muscle protein synthesis during continuous endurance type exercise. Am J Physiol Endocrinol Metab 300: E945-E954, 2011.

2. Biolo G, Tipton KD, Klein S, Wolfe RR. (1997): An abundant supply of amino acids enhances the metabolic effect of exercise on muscle protein. Am J Physiol Endocrinol Metab 273: E122-E129, 1997.

3. Blom PC, Vøllestad NK, Costill DL. (1986): Factors affecting changes in muscle glycogen concentration during and after prolonged exercise.Acta Physiol Scand Suppl.; 556: 67-74.

4. Blom PC, Høstmark AT, Vaage O, Kardel KR, Maehlum S (1987):Effect of different postexercise sugar diets on the rate of muscle glycogen synthesis.Medicine and Science in Sports and Exercise, 19(5):491-496

5. Boeva, B., Angelova, T., Ivanova, V., \& Serafimova, M. (2003). Physical education and sport for ecology directed development of man. Trakia Journal of science, 1(1), 42-43.

6. Borsheim E, Tipton KD, Wolf SE, Wolfe RR. (2002): Essential amino acids and muscle protein recovery from resistance exercise. Am J Physiol Endocrinol Metab 283: E648-E657, 2002.

7. Brun JF, Guintrand-Hugret R, Bouix O, OrsettiA1995 Influence of short-term submaximal exercise on parameters of glucose assimilation analyzed with the minimal model. Metabolism 44:833-840

8. Chen ZP, Stephens JT, Murthy S, Canny BJ, Hargreaves M, Witters LA, Kemp BE, McConell GK (2003): Effect of exercise intensity on skeletal muscle AMPK signaling in humans. Diabetes 52:2205-2212 
9. Drabik, J. (1996). Children \& sports training: How your future champions should exercise to be healthy, fitand happy. Island Pond, VT: Stadion Publiching Company.

10. Despić, D. (1997). Theory of music. Belgrade: Institute for textbooks and teaching aids.

11. Dreyer HC, Drummond MJ, Pennings B, Fujita S, Glynn EL, Chinkes DL, Dhanani S, Volpi E, Rasmussen BB. (2008): Leucineenriched essential amino acid and carbohydrate ingestion following resistance exercise enhances mTOR signaling and protein synthesis in human muscle. Am J Physiol Endocrinol Metab 294: E392-E400, 2008.

12. Elliot TA, Cree MG, Sanford AP, Wolfe RR, Tipton KD. (2006): Milk ingestion stimulates net muscle protein synthesis following resistance exercise. Med Sci Sports Exerc 38: 667-674, 2006.

13. Fujita S, Dreyer HC, Drummond MJ, Glynn EL, Cadenas JG, Yoshizawa F, Volpi E, Rasmussen BB. (2007): Nutrient signalling in the regulation of human muscle protein synthesis. J Physiol 582: 813-823, 2007.

14. Fujita S, Dreyer HC, Drummond MJ, Glynn EL, Volpi E, Rasmussen BB. (2009): Essential amino acid and carbohydrate ingestion before resistance exercise does not enhance postexercise muscle protein synthesis. J Appl Physiol 106: 1730-1739, 2009.

15. Greenberg, CC, Jurczak MJ, Danos AM, Brady MJ. (2006): Glycogen branches out: new perspectives on the role of glycogen metabolism in the integration of metabolic pathways.

16. Am J Physiol Endocrinol Metab 291: E1-E8, 2006

17. Hartman JW, Tang JE, Wilkinson SB, Tarnopolsky MA, Lawrence RL, Fullerton AV, Phillips SM. (2007): Consumption of fatfree fluid milk after resistance exercise promotes greater lean mass accretion than does consumption of soy or carbohydrate in young, novice male weightlifters. Am J Clin Nutr 86: 373-381, 2007.

18. Hasten DL, Pak-Loduca J, Obert KA, Yarasheski KE. Resistance exercise acutely increases MHC and mixed muscle protein synthesis rates in 78-84 and 23-32 yr olds. Am J
Physiol Endocrinol Metab 278: E620-E626, 2000.

19. Jorfeldt L, Wahren J. Leg blood flow during exercise in man. Clin Sci 41: 459-473, 1971.

20. Kim PL, Staron RS, Phillips SM. (2005): Fasted-state skeletal muscle protein synthesis after resistance exercise is altered with training. J Physiol 568: 283-290, 2005.

21. Koopman R, Wagenmakers AJ, Manders RJ, Zorenc AH, Senden JM, Gorselink M, Keizer HA, van Loon LJ. (2005) Combined ingestion of protein and free leucine with carbohydrate increases postexercise muscle protein synthesis in vivo in male subjects. Am J Physiol Endocrinol Metab 288: E645-E653, 2005.

22. Kraniou Y, Cameron-Smith D, Misso M, Collier G, and Hargreaves M. Effects of exercise on GLUT-4 and glycogenin gene expression in human skeletal muscle. J Appl Physiol 88: 794-796, 2000.

23. Koopman R, Beelen M, Stellingwerff T, Pennings B, Saris WH, Kies AK, Kuipers H, van Loon LJ. Coingestion of carbohydrate with protein does not further augment postexercise muscle protein synthesis. Am J Physiol Endocrinol Metab 293: E833-E842, 2007.

24. Kurth-Kraczek EJ, Hirshman MF, Goodyear LJ, Winder WW 1999 5_ AMPactivated protein kinase activation causes GLUT4 translocation in skeletal muscle. Diabetes 48:1667-1671

25. Melendez R, Melendez-Hevia E, and Canela EI. The fractal structure of glycogen: A clever solution to optimize cell metabolism. Biophys J 77: 1327-1332, 1999.

26. Metikoš, D., Milanović, D., Prot, F., Jukić, I., \& Marković, G. (2003). Theoretical and methodological foundation of coordination development. In D. Milanović \& I. Jukić (eds.), Conditional preparation of sportsmen 2003, (pp. 264-270).

27. Mikines KJ, Sonne B, Farrell PA, Tronier B, Galbo H 1988 Effect of physical exercise on sensitivity and responsiveness to insulin in humans. Am J Physiol 254:E248-E259

28. Milenković, D. and Veselinović, N.: Effect of experimental Tae Bo training model for 
coordination development of young women. Sport Science 3 (2010) 2: 57-60

29. Mu J, Skurat AV, and Roach PJ. Glycogenin2, a novel self-glucosylating protein involved in liver glycogen biosynthesis. J Biol Chem 272: 27589-27597, 1997.

30. Petković, E., Veselinović, N., \& StojanovićTošić, J. (2007). Differences in circular dimensionality and subcutaneous fatty tissue at female subjects included at three months Tae bo exercise program.International scientific conference »Physical activity and health « (pp. 81-86). Belgrade: Faculty of sport and physical education.

31. Peter W and Edward CR.: Glycaemic Index and Optimal Performance.Sports medicine 23(3): 1997

32. Rasmussen BB, Wolfe RR, Volpi E. (2002): Oral and intravenously administered amino acids produce similar affects on muscle protein synthesis in the elderly. J Nutr Health Aging 6: 358-362, 2002.

33. Rheaume C, Waib PH, Kouame N, Nadeau A, Lacourciere Y, Joanisse DR, Simoneau JA, Cleroux J 2003 Effects of intense and prolonged exercise on insulin sensitivity and glycogen metabolism in hypertensive participants. Circulation 108:2653-2659

34. Roach P.J Glycogen and its metabolism. Curr Mol Med 2: 101-120, 2002.

35. Sakamoto K, Goodyear LJ 2002 Intracellular signaling in contracting skeletal muscle. J Appl Physiol 93:369-383

36. Shearer J [A], Graham TE, Battram DS, Robinson DL, Richter EA, Wilson RJ, Bakovic M. Glycogenin activity and mRNA expression in response to volitional exhaustion in human skeletal muscle. J Appl Physiol 99: 957-962, 2005.

37. Shearer J [B], Wilson RJ, Battram DS, Richter EA, Robinson DL, Bakovic $M$, Graham TE. Increases in glycogenin and glycogenin mRNA accompany glycogen resynthesis in human skeletal muscle. Am J Physiol Endocrinol Metab 289: E508-E514, 2005.

38. Stephens TJ, Chen ZP, Canny BJ, Michell BJ, Kemp BE, McConell GK 2002 Progressive increase in human skeletal muscle AMPK_2 activity and ACC phosphorylation during exercise. Am J Physiol Endocrinol Metab 282:E688- E694

39. Wilson RJ, Gusba JE, Robinson DL, Graham TE. (2007): Glycogenin protein and mRNA expression in response to changing glycogen concentration in exercise and recovery.Am $\mathrm{J}$ Physiol Endocrinol Metab 292: E1815-E1822, 2007.

40. Wojtaszewski JFP, Nielsen JN, Richter EA 2002 Invited review: effect of acute exercise on insulin signaling and action in humans. J Appl Physiol 93:384-392

41. Zawadzki KM, Yaspelkis BBD, Ivy JL. (1992): Carbohydrate-protein complex increases the rate of muscle glycogen storage after exercise.J Appl Physiol 1992;72:1854-9. 
